\title{
IDENTIFIKASI PEMAHAMAN KONSEPTUAL DAN ALGORITMIK SISWA KELAS XI SMAN 4 BANDA ACEH PADA MATERI TERMOKIMIA TAHUN AJARAN 2014/2015
}

\author{
Ade Ismayani*, M.Hasan, Nuzulia \\ Program Studi Pendidikan Kimia FKIP Universitas Syah Kuala \\ E-mail: ade_ismayani@yahoo.com
}

\begin{abstract}
This study aims to identify the percentage of algorithmic and conceptual understanding on thermochemical lessons in the students of academic year of 2014/2015 grade XI SMAN 4 Banda Aceh. This study will contribute to determine the conceptual and algorithmic understanding of students, so that thermochemical lessons can use appropriate learning models in order to produce high level conceptual and algorithmic capabilities. A simple random sampling was used in this study, in which data was collected by using instrument tests: questionnairesand interviews. The research subjects were 50 students of class XI- IA SMAN 14. This study applied a descriptive quantitative method.. Based on the percentage of conceptual understanding and algorithmic derived on $\mathrm{A} 1 \mathrm{C} 1$ was $8 \%$, A1C0 was $4 \%$, A0C1 was $20 \%$, A0C0 was $0 \%$, and there was $68 \%$ of students who have the algorithmic and conceptual understanding in the middle. This preliminary research is so significant for future research.
\end{abstract}

Keywords: conceptual understanding, algorithmic understanding, thermochemical

\begin{abstract}
Abstrak
Penelitian ini bertujuan untuk mengidentifikasi persentase pemahaman algoritmik dan konseptual siswa pada Materi Termokimia Tahun Ajaran 2014/2015 di kelas XI-IA SMAN 4 Banda Aceh. Penelitian ini dapat memberikan kontribusi dalam mengetahui kemampuan pemahaman konseptual dan algoritmik siswa sehingga pembelajaran pada materi termokimia dapat menggunakan model pembelajaran yang tepat dan menghasilkan kemampuan pemahaman konseptual dan algoritmik yang tinggi. Teknik pengambilan sampel yaitu menggunakan teknik simple random sampling. Subjek penelitian ini adalah siswa kelas XI-IA berjumlah 50 siswa. Metode yang digunakan dalam penelitian ini adalah metode deskriptif kuantitatif. Pengumpulan data dilakukan dengan menggunakan instrumen tes, angket, dan wawancara. Berdasarkan persentase pemahaman konseptual dan algoritmik yang diperoleh pada A1C1 sebanyak 8\%, A1C0 sebanyak 4\%, A0C1 sebanyak 20\%, A0C0 adalah 0\% dan sebanyak 68\% siswa dengan pemahaman algoritmik dan konseptual sedang. Penelitian ini sangat penting sebagai studi pendahuluan bagi penelitian-penelitian lanjutan.
\end{abstract}

Kata kunci : pemahaman konseptual, pemahaman algoritmik, termokimia

\section{PENDAHULUAN}

Belajar dimaknai sebagai kegiatan aktif siswa dalam memahami dan membangun makna terhadap materi yang dipelajarinya. Begitu juga dalam mempelajari 
kimia. Pada umumnya belajar kimia sulit bagi banyak siswa (Gultepe, 2013). Ada banyak faktor yang menghambat siswa belajar kimia yaitu, keterampilan yang memadai seperti algoritmik, struktur hirarkis konsep, buku teks, dan metode pembelajaran. Di semua negara, pemecahan masalah adalah bagian utama dari pendidikan kimia. Kebanyakan guru kimia percaya bahwa pemecahan masalah mengarah pada pemahaman kimia. Meningkatkan kemampuan pemecahan masalah siswa adalah tujuan utama pengajaran kimia, selain itu diketahui bahwa pemecahan masalah adalah bagian yang paling sulit bagi banyak siswa kimia (Bowen \& Bunce, 1997).

Pembelajaran konseptual adalah proses memperoleh pemahaman yang lebih baik dalam konsep dan menerapkannya pada saat siswa memecahkan suatu masalah. Siswa dapat menggunakan pengetahuan baru dalam meningkatkan konsep yang ada untuk meningkatkan cara berpikir mereka. Masalah konseptual merupakan masalah yang memerlukan solusi pemahaman konsep daripada hanya sekadar algoritmik semata. Adapun masalah kuantitatif, memerlukan siswa untuk menggunakan rumus atau bekerja melalui sebuah algoritma untuk menemukan solusi numerik untuk suatu masalah (Bilgin, 2008).

Menurut Surif (2014) dalam pertanyaan-pertanyaan konseptual terdapat 45,96\% siswa yang menunjukkan rendahnya tingkat hasil belajar karena tidak mampu menjawab soal pemahaman konseptual secara benar dan tepat. Hal ini menunjukkan bahwa ada sejumlah besar siswa yang tetap lemah dalam pemecahan masalah konseptual karena pemahaman yang buruk tentang konsep- konsep dasar yang terlibat dalam masalah. Banyak peneliti telah melaporkan kesulitan yang dihadapi oleh siswa ketika mencoba untuk memecahkan masalah konseptual. Oleh karena itu, hal ini akan menjadi indikasi bagi pendidik untuk mencari alternatif lain pendekatan pembelajaran dalam rangka untuk mempromosikan pengembangan pemahaman konseptual kimia siswa.

Banyaknya kecenderungan siswa yang hanya berpusat pada pemecahan masalah secara algorimik membuat siswa akan kesulitan ketika berhadapan dengan pamahaman konseptual. Selain itu, jenis pembelajaran dengan hafalan dan algoritmik, dapat dilihat sebagai faktor lain yang menghambat kemampuan siswa untuk menjawab pertanyaanpertanyaan konseptual. Keseimbangan antara pemahaman konseptual dan algoritmik sangat diperlukan dalam pembelajaran kimia. Penguasaan konsep serta algoritmik 
secara bersamaan diperlukan untuk menghindari terjadinya kesalahpahaman dalam kimia. Johnstone (2006) menyatakan bahwa salah satu materi yang mencakup dua pemahaman tersebut adalah termokimia.

Berdasarkan data yang diperoleh dari guru bidang studi kimia di SMAN 4 Banda Aceh, hasil rata-rata Ujian Harian (UH) siswa pada KD 2.1 dan 2.2 tentang materi termokimia dari tahun 2011 dan 2012 secara berturut-turut adalah 59,12 dan 67,35. Nilai rata-rata UH yang diperoleh tergolong rendah mengingat KKM materi ini yaitu 75. Kesulitan siswa di sekolah ini dalam materi termokimia biasanya terletak pada menentukan harga entalpi pembentukan, entalpi reaksi, dan diagram hukum Hess.

Selain itu, menurut Gabel dkk. (dalam Bilgin, 2008) menyatakan bahwa siswa yang belajar kimia di sekolah menengah atas cenderung untuk memecahkan masalah mengandalkan teknik algoritmik daripada menggunakan keterampilan penalaran. Mereka cenderung tidak menggunakan recall atau evaluasi teknik yang dapat membantu dalam memecahkan masalah dengan benar. Siswa biasanya memiliki kesuksesan yang lebih besar memecahkan masalah yang membutuhkan keterampilan algoritmik daripada pertanyaan yang membutuhkan pengetahuan yang lebih konseptual. Berdasarkan penelitian Adlim dkk (2013) terdapat 67\% siswa mengalami kesulitan pada materi termokimia karena topik ini banyak memuat konsep, matematik, grafik, dan representasi simbolik, yang membuat siswa sulit memahami kimia.

Penelitian ini bertujuan untuk mengidentifikasi persentase pemahaman konseptual dan pemahaman algoritmik siswa pada materi Termokimia. Penelitian ini adalah dapat memberikan kontribusi dalam mengetahui kemampuan pemahaman konseptual dan pemahaman algoritmik siswa sehingga pembelajaran pada materi termokimia dapat menggunakan model pembelajaran yang tepat dan menghasilkan kemampuan pemahaman konseptual dan pemahaman algoritmik yang tinggi.

\section{METODE PENELITIAN}

Metode deskriptif kuantitatif yang digunakan dalam penelitian ini. Metode ini digunakan untuk menggambarkan persentase pemahaman konseptual dan pemahaman algoritmik siswa pada materi termokimia. Dalam penelitian ini, tidak memberikan perlakuan, manipulasi atau pengubahan pada variabel-variabel bebas, tetapi 
menggambarkan suatu kondisi apa adanya. Data dianalisis menggunakan deskriptif persentase. Penelitian ini sangat penting sebagai studi pendahuluan bagi penelitianpenelitian lanjutan.

Penelitian dilakukan di SMAN 4 Banda Aceh dengan subjek penelitian terdiri dari 50 orang siswa yang telah mempelajari materi termokimia. Teknik pengambilan sampel yaitu menggunakan teknik simple random sampling, yaitu teknik pengambilan sampel dari populasi dilakukan secara acak tanpa memperhatikan strata yang ada dalam populasi itu (Sugiono, 2009).

Data penelitian ini dikumpulkan melalui tes, pengisian angket dan wawancara. Tes dalam penelitian ini dibedakan menjadi dua bagian, yaitu tes pemahaman konseptual dan tes pemahaman algoritmik. Proses pengumpulan data yang dilakukan peneliti adalah dengan membagikan soal mengenai materi termokimia, kemudian siswa diminta menjawab soal dengan waktu yang telah ditentukan, yaitu 60 menit. Angket diberikan kepada siswa setelah siswa menyelesaikan soal-soal pada instrumen tes. Tujuannya untuk mengetahui proses belajar-mengajar yang terjadi di kelas dan sebagai data pendukung dalam menganalisis hasil penelitian. Wawancara yang dilakukan oleh peneliti dalam penelitian ini adalah wawancara semi terstruktur untuk mengetahui dengan pasti tentang informasi apa yang akan diperoleh.

Data penelitian dianalisis dengan rumus berikut untuk mengetahui kemampuan algoritmik dan konseptual siswa. Adapun rumusnya:

$$
\mathrm{P}=\frac{f}{N} \times 100 \%
$$

Di mana: $\mathrm{P}=$ angka persentase, $\mathrm{F}=$ frekuensi siswa yang menjawab benar, dan $\mathrm{N}=$ jumlah total siswa.

Papaphotis dan Tsaparlis (2008) membagi persentase pemahaman konseptual dan algoritmik siswa sebagai berikut:

a) Jika siswa mendapat nilai $70-100 \%$ pada soal algoritmik, maka siswa dikatakan memiliki pemahaman algoritmik yang tinggi (HA)

b) Jika siswa mendapat nilai $0-40 \%$ pada soal algoritmik, maka dikatakan siswa memiliki pemahaman algoritmik yang rendah (LA)

c) Jika siswa mendapatkan nilai 50-78\% pada soal konseptual, maka dikatakan siswa memiliki pemahaman konseptual yang tinggi (HC)

d) Jika siswa mendapatkan nilai 0-33\% untuk soal konseptual, maka siswa dikatakan 
memiliki pemahaman konseptual yang rendah (LC)

Untuk memperoleh gabungan kemampuan pemahaman konseptual dan algoritmik dari setiap siswa maka setelah memperoleh persentase masing-masing pemahaman konseptual dan algoritmik digabungkan sehingga diperoleh kategori sebagai berikut :

a) A1C1 : Jika siswa memiliki pemahaman algoritmik tinggi dan pemahaman konseptual tinggi

b) A1C0 : Jika siswa memiliki pemahaman algoritmik tinggi dan pemahaman konseptual rendah

c) A0C1 : Jika siswa memiliki pemahaman algoritmik rendah dan pemahaman konseptual tinggi

d) A0C0 : Jika siswa memiliki pemahaman algoritmik rendah dan pemahaman konseptual rendah

\section{HASIL DAN PEMBAHASAN}

Berdasarkan hasil penelitian yang telah dilakukan, populasi dalam penelitian ini terdiri dari enam kelas paralel. Kemudian subjek penelitian diambil secara simple random sampling dengan jumlah 50 siswa. Data hasil tes yang diperoleh adalah sebagai berikut :

Siswa yang memiliki kemampuan menjawab pertanyaan algoritmik tinggi dan konseptual tinggi (A1C1) sebanyak 8\% yaitu 4 siswa dari 50 siswa. Siswa yang memiliki kemampuan menjawab pertanyaan algoritmik rendah dan konseptual tinggi (A0C1) sebanyak 20\% yaitu 10 siswa dari 50 siswa. Siswa yang memiliki kemampuan menjawab pertanyaan algoritmik tinggi dan konseptual rendah (A1C0) sebanyak 4\% yaitu 2 siswa dari 50 siswa. Siswa yang memiliki kemampuan menjawab algoritmik rendah dan konseptual rendah yaitu 0\%. Selebihnya adalah siswa yang memiliki kemampuan sedang dalam menjawab pertanyaan algoritmik dan konseptual yaitu $68 \%$ dengan jumlah siswa sebanyak 34 siswa.

Berdasarkan hasil penelitian yang diperoleh sesuai dengan data nilai UH pada dua tahun belakangan pada materi termokimia tidak memenuhi KKM yang ditetapkan yaitu 75. Dalam hal ini siswa masih sangat sedikit yang memiliki pemahamaman algoritmik dan atau pemahaman konseptual yang tinggi. Siswa lebih banyak memiliki 
pemahaman algoritmik dan konseptual yang sedang. Oleh karena itu siswa kesulitan dalam memecahkan masalah. Hal ini sesuai dengan pendapat Gabel dkk. (dalam Bilgin, 2008) menyatakan bahwa siswa cenderung tidak menggunakan recall atau evaluasi teknik yang dapat membantu dalam memecahkan masalah dengan benar

Materi termokimia ini termasuk materi yang cukup sulit dan memerlukan pemahaman algoritmik tinggi dan pemahaman konseptual tinggi. Demikian juga berdasarkan hasil wawancara dengan siswa $\mathrm{A} 1 \mathrm{C} 1$, siswa $\mathrm{A} 1 \mathrm{C} 0$, dan siswa $\mathrm{A} 0 \mathrm{C} 1$ menyatakan kesulitan mereka dalam mempelajari materi termokimia. Berikut cuplikannnya:

Wawancara dengan salah satu siswa A1C1:

Peneliti : Apakah Anda mengalami kesulitan dalam memahami bab termokimia? Apa kesulitan yang Anda hadapi?

Siswa X: paling di jenis-jenis entalpi itu... pengertian-pengertiannya...

Wawancara dengan salah satu siswa A1C0:

Peneliti : Apakah Anda mengalami kesulitan dalam memahami bab termokimia? Apa kesulitan yang Anda hadapi?

Siswa Y: kalo saya kadang kurang mengerti pertanyaan dari soal tu bu...kadang gak bisa jawab karena gak ngerti soalnya...harus diarahkan.. ini ini baru oh ini ini...

Wawancara dengan salah satu siswa A0C1:

Peneliti : Apakah Anda mengalami kesulitan dalam memahami bab termokimia? Apa kesulitan yang Anda hadapi?

Siswa Z: lupa bu... termokimia susah ... kalo cari-cari susah...kalo pas diajarin ngerti tapi pas dapat soal udah susah....

Berdasarkan hasil wawancara yang dilakukan dengan siswa A1C1 dan A1C0 lebih menyukai algoritmik daripada konseptual. Akan tetapi, siswa A1C0 yang memiliki pemahaman algoritmik lebih tinggi tidak mampu memperoleh pemahaman konseptual yang tinggi. Hal ini sesuai dengan yang dikatakan Gultepe (2013) yaitu bahwa kemampuan algoritmik siswa yang tinggi tidak menjamin kesuksesan siswa 
dalam menjawab soal yang konseptual. Adapun siswa A0C1 lebih menyukai pemahaman konseptual. Meskipun demikian, siswa A0C1 tetap menyatakan soal algoritmik lebih disukai dari pada soal konseptual, karena terkadang soal konseptual lebih sukar dipahami dibanding soal algoritmik. Dalam beberapa kasus, juga terdapat siswa yang tinggi dalam konsep, namun tidak mampu mengimplementasikannya dalam algoritmik (Chiu, 2001).

Siswa juga dibagikan angket untuk mengetahui kebutuhan akan siswa pada materi ini. Angket tersebut dihitung dengan menggunakan skala Likert. Angket yang diperoleh menunjukkan skor 4539. Skor tersebut berada pada rentang 3864 sampai dengan 5152 yang dikategorikan lebih mendekati setuju, artinya guru sebaiknya menyeimbangkan penyampaian antara pemahaman algoritmik dan konseptual, karena keduanya penting. Siswa tidak boleh berpusat dalam salah satu pemahaman saja dalam mempelajari kimia, namun harus memahami baik algoritmik maupun konseptual agar dapat memahami materi secara utuh. Dalam pembelajaran termokimia masih terdapat guru yang menyampaikan materi, hanya berpusat pada salah satu pemahaman saja. Materi termokimia merupakan salah satu materi yang mencakup dua pemahaman tersebut. Hal ini sesuai dengan yang disampaikan oleh Johnstone (2006) bahwa keseimbangan antara pemahaman konseptual tinggi dan pemahaman algoritmik tinggi sangat diperlukan dalam pembelajaran kimia.

\section{KESIMPULAN}

Berdasarkan hasil penelitian dan pembahasan mengenai identifikasi pemahaman konseptual dan algoritmik siswa kelas XI SMA Negeri 4 Banda Aceh pada materi termokimia dapat disimpulkan bahwa persentase siswa yang memiliki pemahaman algoritmik tinggi dan konseptual tinggi adalah (A1C1) sebanyak 8\%, algoritmik tinggi dan konseptual rendah (A1C0) sebanyak 4\%, algoritmik rendah konseptual tinggi (A0C1) sebanyak 20\% dan algoritmik rendah dan konseptual rendah (A0C0) yaitu $0 \%$. Selebihnya adalah siswa yang memiliki kemampuan sedang dalam menjawab pertanyaan algoritmik dan konseptual yaitu 68\% dengan jumlah siswa sebanyak 34 siswa. 


\section{DAFTAR PUSTAKA}

Adlim, Soewarno, Hasbi Ali, Armia Ibrahim, Hasmunir Umar, Khairil Ismail, Usman A. Gani, Ishak Hasan and Burhanuddin Yasin. 2013. Assessing Chemistry-Learning Competencies of Students in Isolated Rural senior High School by Using the National Examination: A Case Study of Simeulu Island, Indonesia. International Journal of Science and Mathematics Education, 12(4): 817-839.

Bilgin, I. 2008. The Effect of Problem-Based Larning Instruction on University Students' Performance of Conceptual and Quantitative Problems in Gas Concept. Eurasia Journal of Mathematis Science \& Technology Education, 5(2): 153-164.

Bowen, C. W., and Bunce, D. M. 1997. Testing for Conceptual Understanding in General Chemistry. The Chemical Eucator, 2(2): 1-17.

Chiu, M. 2001. Algoritmic Problem Solving and Conceptual Understanding of Chemistry by Student at A Local High School in Taiwan. Proc. Natl. Sci. Counc, 11(1): 20-38.

Gultepe, N., Celik, A.Y., and Kilic, Z. 2013. Exploring Effects of High School Students' Mathematical Processing Skills and Conceptual Understanding of Chemical Concepts on Algorithmic Problem Solving. Australian Journal of Teacher Education, 38(10): 106-122.

Johnstone, A.H. 2006. Chemical Education Research in Glasgow in Perspective.

Review of research.

Sugiono. 2009. Metode Penelitian Kuantitatif, Kualittif, dan $R \&$ D. Bandung: Penerbit Alfabeta.

Surif, J., Ibrahim, N.H., and Dalim, S.F. 2014. Problem Solving: Algorithms and Conceptual and Open-Ended Problems in Chemistry. Procedia - Social and Behavioral Sciences, 116: 4955 - 4963.

Sudjana, N.S. 2007. Metode Penelitian Pendidikan. Bandung. Remaja Rosda Karya. 